\title{
History and Stories. The politics and poetics of mining narratives in the South Pacific
}

\section{Pierre-Yves Le Meur and Eddy Banaré}

Translator. Susan Cox

\section{(2) OpenEdition Journals}

\section{Electronic version}

URL: http://journals.openedition.org/jso/7590

DOI: $10.4000 /$ jso. 7590

ISSN: $1760-7256$

\section{Publisher}

Société des océanistes

\section{Printed version}

Date of publication: 15 December 2014

Number of pages: 5-22

ISBN: 978-2-85430-118-2

ISSN: 0300-953x

\section{Electronic reference}

Pierre-Yves Le Meur and Eddy Banaré, «History and Stories. The politics and poetics of mining narratives in the South Pacific », Journal de la Société des Océanistes [Online], 138-139 | 2014, Online since 15 March 2017, connection on 24 September 2020. URL : http://journals.openedition.org/jso/ 7590 ; DOI : https://doi.org/10.4000/jso.7590 


\title{
Introduction : History and Stories. The politics and poetics of mining narratives in the South Pacific
}

by

\author{
Pierre-Yves LE MEUR ${ }^{*}$ and Eddy BANARÉ ${ }^{* *}$
}

\begin{abstract}
"Contemporary literary theory is much too useful to let it be limited to the domains of critique, reflexivity, and value pluralism alone." (Roe, 1994 : 10)
\end{abstract}

The aim of this special issue is to highlight both the diversity and points of convergence of the issues raised by mining in the Pacific region and, moreover, through the lens of the narratives formulated around the activity: What kind of stories are told about mining? Who tells them, in what context, for what purposes and to what effect? The essays collected here explore this topic by analyzing and contextualizing the texts, situations and historical legacies, and the artistic products and productions that constitute the narrative form In addition, Placer $s$ about mining in the Pacific. ${ }^{1}$ What is involved here is the demonstration of the variety of human experiences relating to mining in this region through the multiplicity of narratives that evoke the discourses, practices and representations relating to this very particular object and issue.

We begin this introduction with the subject itself, that is the mine in its materiality, both as a physical enclave, in which a specific work process is carried out (Sidaway, 2007), and in its external 'overflow' (Letté, 2009), that is its impacts on the surrounding society. This first section enables us to establish a basis for the consideration of the way in which narrative forms that relate to this subject and/or its impacts in very different ways are constructed. The second section outlines the semantic field defined by the concept of narrative based on literary theory. In the third section, we extend the issue in the direction of the philosophical, political and anthropological uses of the concept of narrative - in particular narratives that do not have a clearly defined author but do not lack narrators: master narratives, metanarratives and public policy narratives - before returning, finally, to the question of the narrator in the forms of 'emplotment' involving mining in the Pacific.

As we shall see, the emplotment of a narrative is based on different modes: a link between time lived and time told and between narration and action to the extent that "by virtue of the plot, aims, causes, coincidences, risks are assembled under the temporal unit of a total and complete action" (Ricœur, 1983: 9). Therefore, it is essential to note that while this volume presents an

1. Some of the texts (Banaré, Bencivengo, Chaloping-March, Edwards, Leach, Pollock) arose from presentations made at the conference entitled "Mining and Mining Policy in the Pacific: History, Challenges and Perspectives" (IRD-SPC-IAC-COARAIL-CIRAD-UNC-CNRT "Nickel and its environment") held in Nouméa from 21 to 25 November 2011. They were revised to produce the final versions published here. Other presentations provided material for an anthology to be published by ANU Press (see Filer et al., in press). We would like to express our sincere thanks to Michel Jébrak, Dan Jorgensen, Claire Levacher, the editing committee of the $J S O$ and the anonymous reviewer for their work and comments.

*Anthropologist, Institut de recherche pour le développement (IRD, UMR GRED), pierre-yves.lemeur@ird.fr

${ }^{* *}$ Holds a doctorate in literature and is a research associate at the Centre des nouvelles études du Pacifique (CNEP, University of New Caledonia), eddy.banare@gmail.com 
important sample of the diversity of mining narratives, it is not exhaustive or completely representative of their variety and depth. The majority of these texts are pervaded by 'authorless narratives', that is the narratives of colonization, development and resource curse and some of them adopt this aspect as their central focus (for example, Bencivengo, Chaloping-March). The more ethnographic approaches vary between establishing a link between the narrative type and actor group in the context of an analysis of a mining arena (in particular Burton), on the one hand, and an emphasis on the variety of the narratives and practices developed by the populations affected by the mine, on the other (in particular Bacalzo et al., Jorgensen, Leach). Depending on the essay in question, the concept of a narrative, as developed in this introduction in terms of its characteristics and interest, is either applied intensively (Banaré for the field of literature, Giulani in more metaphorical terms for the field of art) or acts as an analytical frame that enables us to put historical case studies into perspective (Edwards, Nanau).

\section{Mining in the Pacific: narrative and materiality}

Mining in the Pacific is characterized by its diversity or, more specifically, its incorporation into the specific historical trajectories of territories and countries with different fates. An often major economic, social and environmental phenomenon, mining spanned the colonial period and continued to leave its mark on the countries and territories of a region characterized by a delayed transition to decolonization. Its political implications and socio-environmental impacts are extremely diverse. Depending on the location in the Pacific region in which it was carried out, mining managed to act as a trigger of environmental disasters, an instigator of processes of economic development and even a factor in political unrest (see Ballard and Banks, 2003; Bebbington et al., 2008). The 1990s were less about the discovery of the damage caused by mining operations than the extensive media coverage of it. In terms of their actual scale and due to the effects of the publicization of these crises on the reputation and strategies of the responsible companies, two particular cases of such damage are emblematic for the Asia-Pacific zone: the environmental disaster of the Ok Tedi gold and copper mine in Papua New Guinea. The latter was operated by a consortium led by BHP Billiton, the ravages of which were identified in the 1980s and became a focus of public attention in the 1990s (see Ballard and Banks, 1997; Hyndman, 2005; Kirsch, 2006). The leaking of toxic substances from the tailings dams into the rivers downstream of the Marcopper gold mine operated by the Canadian company Placer Dome in the Philippines in 1996 also attracted considerable attention (Dashwood, 2013: 137, 141-142; Chaloping-March here). ${ }^{2}$ In addition, Placer Dome had already been taken to task for the damage caused by the chemical products used to extract gold from the ore in the Misima and Porgera mines in Papua New Guinea. Furthermore, the social violence instigated around the Porgera mine, the acuity and persistence of which John Burton reminds us here (pp. 37-51) (see also Filer, 1999), clearly demonstrates the limits of the measures adopted by the companies (in the context of corporate social responsibility; see Filer et al., 2008; Dashwood, 2013) and the states (the Development Forums established in Papua New Guinea from 1989 and analyzed by Filer, 2012). The Grasberg gold and copper mine in Indonesian Papua is a paradigmatic example of clientelist collusion - in this instance between the Texan company Freeport-McMoRan and the highest echelons of the state and military hierarchy in Indonesia. Unfortunately, the post-Suharto transition in 1998 did not bring about any major change in this regard (Ballard and Banks, 2009). This direct 'hook up' between companies and the national state arena - a form of institutional and political enclave - makes an abrupt contribution to the reproduction of the physical enclave of the mine by making the local forces of repression available to its operations: environmental, social and political violence mutually reinforce each other here to a rarely paralleled extent (Leith, 2003). Finally, the case of the Panguna copper mine on the island of Bougainville, again in Papua New Guinea, tragically symbolizes the spreading of an environmental, social and political crisis which culminated in a bloody civil war (see, in particular, Filer, 1990).

The environmental impact of the mining operations was also the subject of major controversies in New Caledonia, including in the scientific world (Richer de Forges et Pascal, 2008). ${ }^{3}$ Nevertheless, its contribution to the

2. The terms used to describe these events are also part of the process of creating a narrative and the controversies that accompany it. We had to wait until 1999 for BHP to describe the damage caused by the operation of the Ok Tedi mine as an "environmental disaster" (Asia Times online of 13 August 1999; http://www.atimes.com/oceania/AH13Ah01. $\mathrm{html}$ ). In the case the breaching of the dam containing the chemical residues from gold mining in Omai in Guyana, the environmental community referred to an "environmental catastrophe" while the engineers, consultants and mining companies spoke of an "environmental incident" (Dashwood, $2013: 141$ ).

3. See, in particular, the internal controversies at the IRD centre in Nouméa between 2004 and 2008, which resulted in the disbanding of a research department. These controversies are traced and analyzed by Julien Merlin in his doctoral 


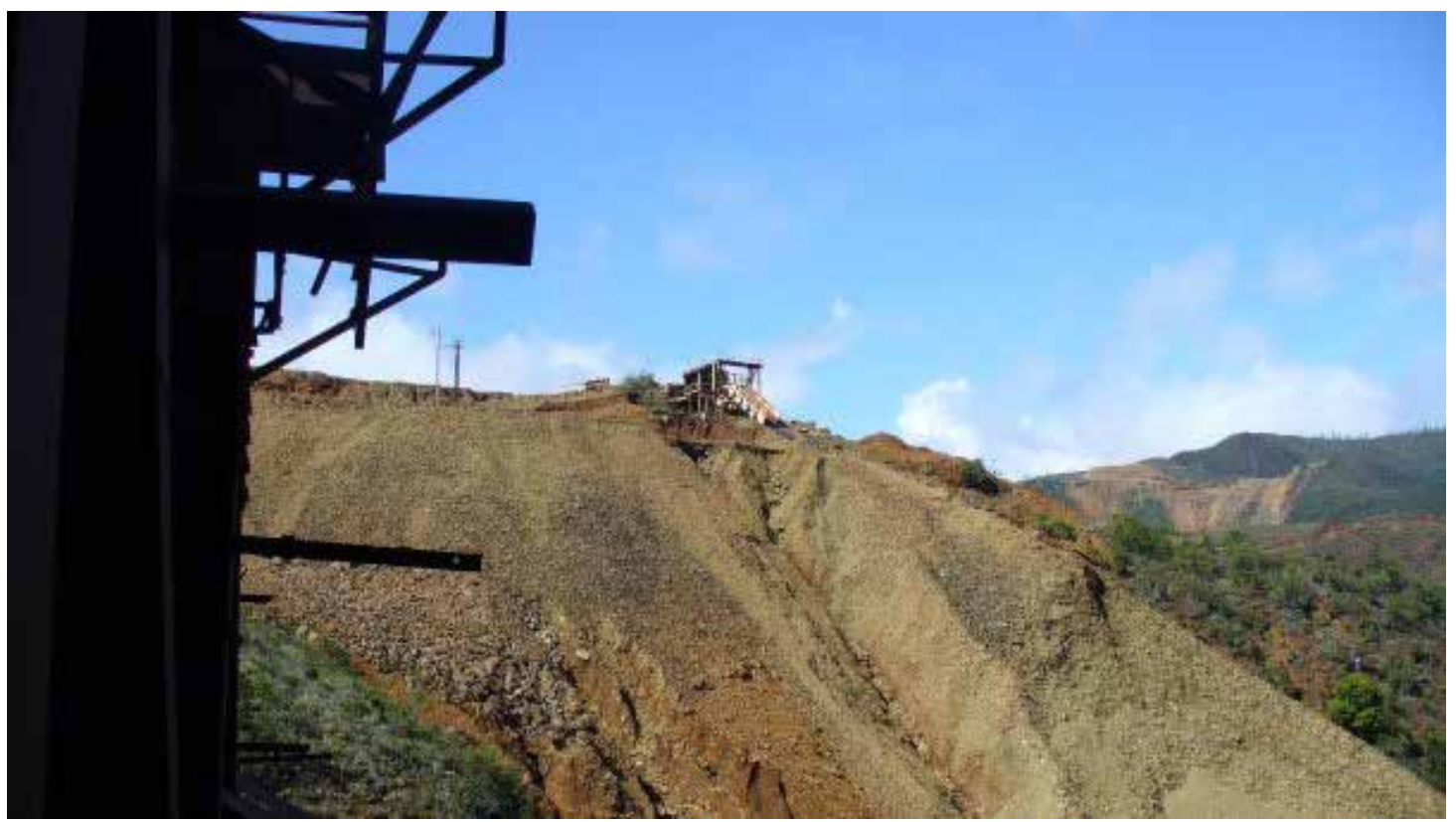

Рното 1. - - Abandoned Kaa Wi Paa de Kouaoua mine (New Caledonia) (2008, ( ) Eddy Banaré)

country's development and decolonization has also been highlighted (Grochain et al., forthcoming). The case of Nauru, which is examined by Nancy Pollock in this volume (pp.107-119), ultimately emerges to be a dramatic combination of an environmental disaster and failure of development. Mining also gave rise to land-related and political-cultural problems when the establishment of mines affected areas with significant symbolic and heritage associations. In other words, mining - like land - is a matter of "power, wealth and meaning" (Shipton and Goheen, 1992). It leaves a permanent mark on contemporary Oceanic societies by putting the future of the local populations at stake in an often conflictual manner. As an activity and project mining is built on confrontation, the confrontation between people and nature and the confrontation between points of view, representations, strategies, action logics and interpretations relating to the issues it introduces or alters.

The practice of mining is inseparable from its narrativization: the narrativization of a non-mining past, a glorified or difficult present, a future that is characterized by extreme uncertainty at times and considerable certainty at others. The representations of the work and effects of mining in history and literature can provide very revealing insights into the way in which mines have shaped the imaginations and representations of the populations and institutions affected by the activity. The temporal dimension, for example whether the perspective is located in the 'before', 'during' or 'after' of the mine, or, again, based on the historical resonance of the presence of mining in a location, have a major influence on the interpretation and understanding of local expectations (see Polier, 1996; Imbun, 2011; see also Nash, 1993, her seminal work on the case of Bolivia, and Taussig, 2010).

We are interested here in all of the different types of narratives generated by this activity, irrespective of whether they originate from field studies, public policy documents, archive sources or creative writing, and investigate a series of questions: How does mining feature in the major community and/or national narratives in the Pacific region? How does it contribute to the renewal or reactivation of the narratives and myths of origin and the development of collective memories? In which context and based on which factors does it shift from the status of an economic activity with negative impacts on the environment to that of a historical heritage, which is valued as a memorial and material extension of a group? In short, how and at what level (i.e. local, national, global) does it sustain or, conversely, prevent the creation of what Benedict Anderson (1983) referred to as "imaginary communities" (on post-colonial Melanesia, see also Foster, 1995, 2002)? As we shall see, by focusing on the analytical level, the texts collected here each respond in part to these political questions. Thus, the question regarding the "nationalism of resources", which is explored 
by Minerva Chaloping-March (pp. 93-106), is being resolved in the Philippines in the context of controversies which put the central state and the provincial and local political-administrative levels allied with civil society groups in opposing camps regarding the valid definition of the common good, to which the mining development is supposed to contribute. This kind of debate, which concerns the forms of 'localization' of mining and its effects arises in Papua New Guinea but, as demonstrated by Dan Jorgensen in particular, it develops in scalable narrative spaces ranging from the local to the global.

\section{Mining narratives: constituent elements}

The use of the term "narrative" or "narrativization" requires us to clarify this potentially polysemous term. In Narrative Discourse, the narratologist Gérard Genette differentiates between three meanings. Narrative can refer "to the narrative statement, the oral or written discourse that undertakes to tell of an event or a series of events", "the succession of events, real or fictitious, that are the subjects of this discourse, and to their several relations" or "the act of narration taken in itself (1983: 24-26). Genette opted to limit the use of the term 'narrative' to the first sense "signifier, statement, discourse or narrative text itself." He also refers to, second, "story" or "diegesis" (ibid.: 27), that is "signified or narrative content", and "narrating", the third, which corresponds to "the producing narrative action and, by extension, the whole of the real or fictional situation in which that action takes place" (ibid.: 27).

Gérard Genette's object of study is literature (In Search of Lost Time by Marcel Proust in this book) and, specifically the limited sense of the term narrative:

"[...] of the three levels we have just sorted out, the level of narrative discourse is the only instrument of examination at our disposal in the field of literary narrative, and particularly fictional narrative. " (ibid.)

The area of investigation tackled by this collection is broader and the authors assembled here obviously deploy other tools apart from the text - and, hence, the narrative as signifier (in the first sense specified by Genette) - to support their discourses: i.e. archaeological evidence, ethnographic materials, archive sources, scientific data, artistic installations.

Gérard Genette responds to the criticisms of the first text in Narrative Discourse Revisited, which he wrote a decade later. In this work, he refines, in particular, the connection between narrative, story and narrating, depending on whether the register in question is fictional or not.

«In a nonfictional (for example, historical) narrative, the actual order is obviously story (the completed events) - narrating (the narrative act of the historian) - narrative (the product of that act, potentially or virtually capable of surviving it in the form of a written text, a recording, or a human memory. " (Genette, 1988: 14)

\section{He adds:}

«As a matter of fact, only this remanence justifies our regarding narrative as posterior to the narrating. Narrative in its earliest occurrence - oral or even written - is wholly simultaneous with narrating, and the distinction between them is less one of time than of aspect: narrative designates the spoken discourse (syntactic and semantic aspect, according to Morris's terms) and narrating the situation within which it is uttered (pragmatic aspect).» (ibid.)

It could be suggested that this is the precise space, in which something that is traditionally referred to in historiography as the 'criticism of sources' is used: i.e. the (partial) understanding of the narrative through the analysis of the conditions in which it was produced. In the case of both direct sources and sociological texts this enables the testing of the 'plausibility' of an interpretation (Passeron, 1991). To return to Gérard Genette:

«In fiction, the real narrative situation is pretended to $[\ldots]$. But the true order is instead something like narrating $\rightarrow$ story/narrative, with the narrative act initiating (inventing) both the story and its narrative, which are then completely indissociable " (Genette, 1988: 15)

However, although it involves ideal types, the construction of narrative sequences relating to fictional or historical situations ${ }^{4}$ differs: "But has a pure fiction ever existed? And a pure nonfiction?" (Genette, 1988: 15; see also Ricour, 1983-1985). This blurred boundary, the interface where ideas such as that of narrative identity (to which we will return) and the question of interpretation in the field of the social sciences develop is of interest to us here. We concur here with Jean-Pierre Olivier de Sardan when he states that:

" "[the] epistemological space specific to the social sciences is [...] both entirely interpretative and empi-

4. Historical in the sense of narratives incorporated into the historical universe of the societies and the sciences dedicated to their study. 


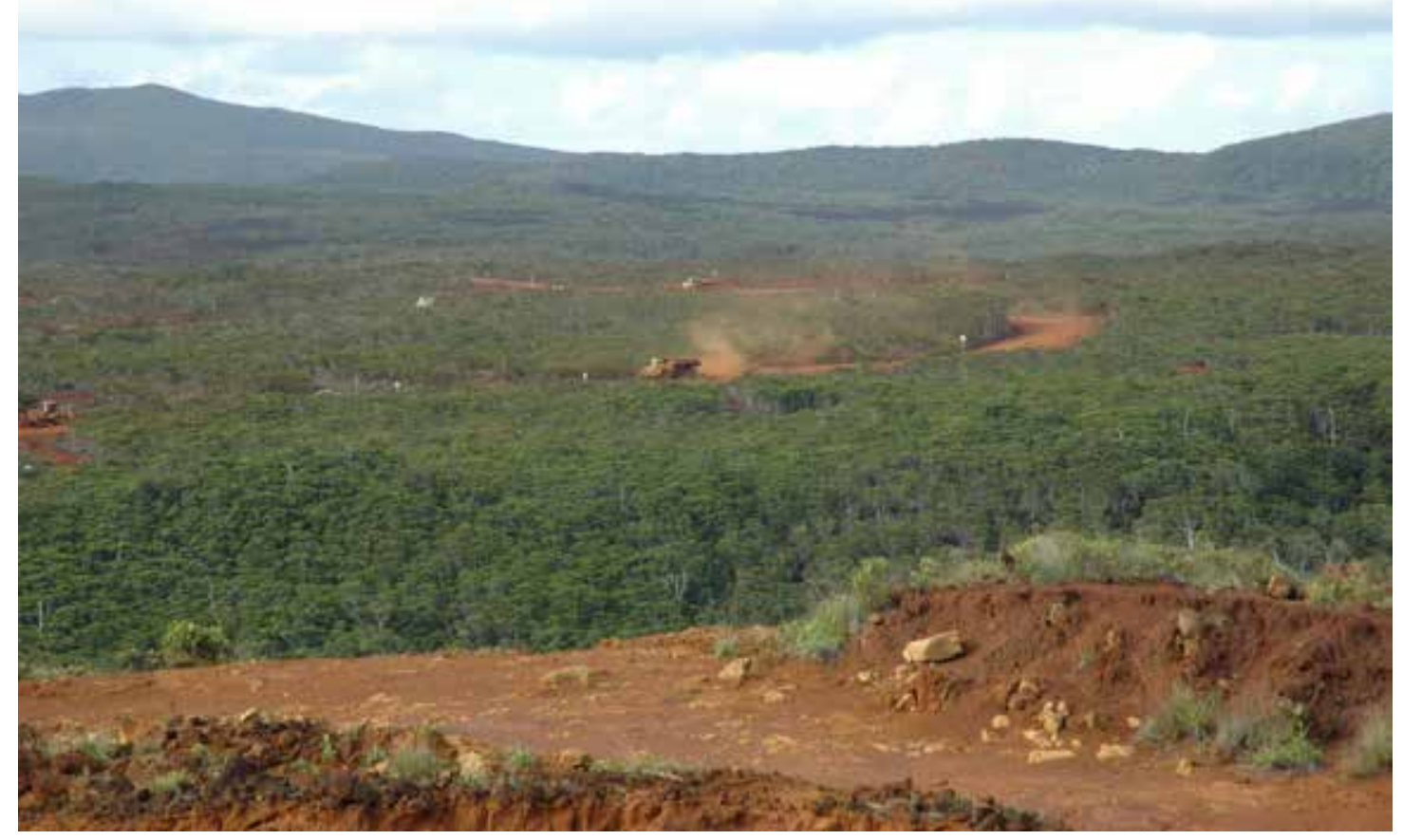

Рното 2. - Haulage in a mining landscape, Goro (south-west of the island of Grande Terre, New Caledonia) (April 2007, (C) Isabelle Leblic)

rically limited. »(Olivier de Sardan, 2008 : 266-267, our translation)

In this context, the legitimation of all interpretative statements is based on a certain 'veracity index', a link to the 'real' that can be retraced (or contested). Having acknowledged this, the inclusion of literary studies and artistic representations in this study on mining enables us to broaden the content and avail of the theoretical corpus provided by the experts in literary narrative and semiotics. In his contribution on the mining literature of $\mathrm{New}$ Caledonia (pp. 151-164), Eddy Banaré suggests that, based on an intertextual logic, literary studies can allow themselves to compare points of view:

"by choosing to consider, for example, that the vision of mining landscapes of a Kanak poetess [...] during 'les Événements' (revolution of 1984-1988) could constitute a given response to a colonial commentator of the late nineteenth century. " (p. 152, our translation)

This intertextual logic is very prevalent, moreover, in the narratives presented here by Dan Jorgensen, specifically in the Christian re-wri- ting of the Afek myth of origin and the analogy drawn by certain informants between the Faiwol language and that of the Old Testament and indicators of intertextuality can also be implicitly identified in James Leach's contribution. Hence, it is not a question of distancing oneself from historical chronology as Carlos Fuentes opted to do in his extraordinary Terra Nostra (1979) or of making a plea for anticipatory plagiarism like Pierre Bayard (2009). ${ }^{5}$ The challenge, instead, is to spot repetitions or legacies or, again, to situate the points of view and identify potential dialogues beyond the temporal irreversibility. It is also necessary to take the "historical ecology" into account (Clifford, 2013: 42), in which indigenous people (but obviously not exclusively) evolve, an extended period characterized by a dual orientation towards the past and the future, based on the image of the spiral evoked by Epili Hau'ofa (1993). In a study devoted to the Yolngu people from Arnhem Land in the Northern Territory of Australia, Ian McIntosh shows that the both historical and mythical roots of the Yolngu people's long-term relationship with the issue of mining, particularly in the context of relationships with fishermen originating from Sulawesi, which were established in the late eighteenth and early nineteenth, strongly oriented the interpretation

5. Along with quotation and allusion, plagiarism is one of the three forms of intertextuality acknowledged by Genette in his limited acceptance of intertextuality as a relationship of co-presence between two texts or several texts and the presence of one text within another (Montalbetti, 1998: 64). 
of the contemporary emergence of the mining industry:

"There is a complete subordination of history to the ideology of Dreaming. [...] To follow the law and realise a pre-ordained future, mining must occur, but only on aboriginal terms. " (McIntoch, $2004: 26$; see also Jorgensen, 1990 et infra)

To go further with the establishment of a dialogue between the social sciences and the fields of art and literature, we will continue to use the categories proposed by Genette in his discourse on narrative which borrow from the grammar of the verb (Montalbetti, 1998: 50-56): i.e. tense, mode, voice. Tense incorporates order - which concerns eventual lags or anachronisms between the sequence of events in the story and their representation in the narrative -, duration or speed - which expresses the differences in rhythm between story and narrative -, and frequency - narratives can be repetitive or iterative to varying degrees. Mode refers to the distance between the narrator and the event - maximum distance in a narrativized discourse, minimal in a reported discourse - and the adopted perspective (or focus). In other words, the narrator says more or less what the person knows and this raises among others the perennial question of the omniscient narrator in literature ("zero focus"). The question of mode can also concern the social sciences, at least certain approaches inspired by structuralism which aim to disclose structures or unconscious causes to the social actors. Voice relates to the identification of the narrating instance which is not necessarily the author (Genette, 1988). It is partly a matter of temporality as it situates the narrative in time in relation to its system of reference: in most cases later (a past event is narrated), previous in the case of a predictive narrative, and simultaneous or interspersed when the narrative develops between moments of action. Genette also differentiates between levels of narrating within this category of voice, with the possibility of the interweaving of one narrative into another. The main opposition is located between the extradiegetic level of the narrator, who is external to the narrative, and the diegetic (or intradiegetic) level of the characters' narratives. ${ }^{6}$ The second opposition, which is of particular interest to us here, arises between a homodiegetic narrative, when the character-narrator himself participates in the elements of the narrative he is recounting (if he is the hero of the narrative, we refer to an autodiegetic narrative), and a heterodiegetic narrative, when he is not involved in the story he is narrating. ${ }^{7}$

The wavering of anthropological narratives in relation to the acts and words of the investigated persons and the more or less discreet intrusion of the figure of the anthropologist correspond to the heterodiegetic-homodiegetic/autodiegetic pair - at least for those who forget Smith's aphorism as quoted by Sanjek:

"The subjects of ethnographies, it should never be forgotten, are always more interesting than their authors. " (1990: 610)

The other tension that structures ethnographic narratives was incisively decoded by Johannes Fabian; it concerns the topic of allochronism and, more specifically, what he refers to as the "denial of coevalnes" on the part of anthropological narratives (1983: 31), which gives rise to a schizogenic relationship with time (ibid.: 35): the constitutive coevalness of the ethnographic terrain is erased in the establishment of narratives which equally involve the establishment of distance from the 'other', or a rejection of his historicity. While ethnographic writing has succeeded in evolving since this book (Clifford and Marcus, 1986; Dawson et al., 1997; see also Fabian, 2006), ${ }^{8}$ particularly with the birth of a dialogical anthropology which is alert to situations involving interlocution ${ }^{9}$ (see Masquelier and Siran, 2000), we shall see that the narratives established in the context of legitimizing public policies, in this instance mining policies, function in accordance with mechanisms that are similar to those described by Fabian. An essential difference arises from the identification of the narrator and, above all, the author. We must now extend our reflections in the direction of uses of the concept of narrative

6. The metadiegetic level corresponds to the taking over of a narrative within the story or diegesis, which can give rise to a series of narrative embeddings (The Thousand and One Nights and Italo Calvino's If on a winter's night a traveller come to mind here). Finally, Genette differentiates between six functional types in the relationships between the metadiegetic level and primary narrative (extradiegetic), in which he incorporates: the explanatory function, predictive function, thematic function, persuasive function, distractive function, obstructive function (Genette, 1988: 93-94; for an initial typology in three classes, see 61-63).

7. See also Davies (1999: 218-219) who refers to metanarrative to designate the organization of plural primary narratives carried out by ethnographic writing.

8. This is also true of historical writing which has been the subject of profound debate, particularly in relation to the concept of narrative and the rejection - and then return - of the event (see, in particular, Burke, 1991; Hartog, 2003: 202-215 and 2005; White, 2009).

9. The topic of rhetoric, of discourse as constituent of society, was developed in Oceanic anthropology (Brenneis and Myers, 1984; Gegeo and Watson-Gegeo, 1990) but not in the field of mining and from the more narrative perspective discussed here. 
that are not literary but philosophical, political and anthropological.

\section{Mining: between master narratives and small stories}

The idea of the 'master narrative' (grand récit) was deployed by the very people who heralded its demise, that is philosophers usually described as 'post-modern', for example Jean-François Lyotard:

"Simplifying to the extreme, I define postmodern as incredulity towards metanarratives. " (Lyotard, 1984: XXIV)

Or, as Emery Roe tersely declares in reference to Lyotard in his book on policy narratives: "Metanarratives have gotten a very bad press lately" (1994: 52; see also Clifford, 2013: 4041). Lyotard is particularly interested in the role of the narrative function in the legitimation of scientific knowledge, the undercurrents of which may be political or philosophical in nature (1984: 23f). The master narratives of Enlightenment, modernization or development may be interpreted in terms of the relationship with knowledge (the scientific knowledge of the period in which the narrative originated, which is often outdated, gradually settles into an ideological substrate), but also in terms of the relationship with time: "A modern future set against a primitive present", as Frederick Cooper (1997: 65) states in relation to colonial (and postcolonial) development as a discursive practice.

The justification of mining was often translated through such development and modernization discourses - be it in relation to the colonial or post-colonial period. Yann Bencivengo (pp. 137149) clearly demonstrates how the company Société Le Nickel emerged in New Caledonia at the junction of several trajectories: that of the birth of the nickel industry, that of French colonial history, and, specifically, that of New Caledonia as a locus of settlement colonization, racial and spatial segregation, and the import of external labour. ${ }^{10}$ The mining narratives, be they those of individual prospectors, of a future hegemonic enterprise on the entire territory of New Caledonia like the SLN, or the literary narratives referred to by Banare, are located at the intersection of these trajectories (see also Banaré, 2012, 2014). The distinction between narrative and story (i.e. diegesis as defined by Genette, cf. above) proposed by Sivaramakrishnan is useful at this point:

"[...] development - as it is imagined, practiced, and re-created - is best described as stories that can change in their telling, as they are pieced together into contingently coherent narratives. Development's stories are rife with a micropolitics often obscured by the consistency or more orderly progression implied by the terms discourse or narrative. " (Sivaramakrishnan, $2000: 432$ )

Like the narrative of Higginson, one of the founders of the SLN, which was reported by Thompson (2000), whether they are direct, reported (in the press of the time) or formed (also fictionalized) by writers, the narratives of the pioneers are all heterogeneous individual stories. Nevertheless they have certain recurrent characteristics that come within the scope of the 'colonial narrative', i.e. the success of the pioneer (white, male) 'developing' new ("vacant and ownerless") lands and of the western civilizing mission. The identification of the author of the specific stories would appear to be a simple affair ranging between hetero- and homodiegetic postures while the colonial narrative appears to lack one. ${ }^{11}$ This is not to say that narratives that do not have an author lack narrators (and narratees in the sense of Genette: i.e. the intended targets of the narrators); this is the point of the social and political indexation of these narratives, their uses, and the strategic and representational logics of which they are part.

Policy narratives are part of the authorless narratives involving analysis in terms of structure (or morphology) and, to adopt the term used by Propp (1970), functions. ${ }^{12}$ Policy narratives all present in the form of a narrative sequence of causal relations aimed at underpinning a certain thesis; their function is to legitimize a political orientation (Roe, 1994; Mosse, 2004). Emery Roe explains their role in the consolidation of an argument for the purpose of justifying decisions in contexts characterized by uncertainty, complexity or the polarization of the question under discussion (1994: 3). He starts with a simple definition of the narrative as story or diegesis:

10. On the specific case of the import of Japanese labour into New Caledonia, see also Bencivengo (2012).

11. Somewhat similar to the way in which the law develops as a statement regime which has "the peculiarity of preceding all statement originators" (Latour, 2002: 298).

12. In his analysis of the morphology of the folktale, Propp locates the structural "functions" which organize such tales: "Function is understood as an act of a character, defined from the point of view of its significance for the course of the action" (Propp, 1968: 21). He adds: "a tale often attributes identical actions to various personnages"; the French edition is more specific: "a tale often attributes identical actions to human beings, things and animals" (1970: 12). This comes close to semiotics expert Greimas's actant (see Greimas and Courtès, 1993: 3-4) as adopted in Latour and Callon's sociology of the actor. 
"If they are stories, they have beginnings, middles and ends, as in scenarios; if the stories are in the form of arguments, they have premises and conclusions." (Roe, 1994: 3)

"Each relates a succession of events, real or hypothetical.» (ibid. : 53)

Roe then provides a more complex definition of narrative by adding "nonstory", "counterstory" and "metanarrative, with a small ' $m$ ' as he explains on a number of occasions (as opposed to the Metanarratives or "master narratives" of reason or science, for example; ibid: 12), to the category of "story". A counterstory constitutes an alternative or opposing narrative to the dominant one while a nonstory differs through its structure, which differs from the linear structure of the narrative and includes circular arguments, for example. The metanarrative is a second order narrative inferred by the analyst based on the comparison of the different stories, counterstories and nonstories that constitute a political controversy. Roe sees a potential new narrative in this metanarrative that would make it possible to go beyond the contradictions between the stories and counterstories and construct an argument that is more adapted to the political question at stake:

"Today's metanarratives are tomorrow policy narratives, to be superseded at a later date. " (ibid. : 17)

Let us take an example involving phosphate mining in Nauru dealt with by Nancy Pollock (pp. 107-119) in this volume: the 'resource curse' thesis. This is one of the most powerful policy narratives in force, particularly in relation to the issue of mining. Pollock proposes a narrative of environmental and social disaster created by phosphate mining in Nauru and consisting of a causal sequence, which can be shaped somewhat teleologically using the concept of a 'curse' in that the (provisional) conclusion of the story is already known. This narrative is rooted in a colonial genealogy which enlists both the discourse of the terra nullius (i.e. land that does not have an owner sufficiently civilized to be recognized as such), where necessary constructing this vacant territory through population displacement (a mechanism also explored by Julia Edwards in Banaba (pp. 121136; see also Shlomowitz and Munro, 1992), and a policy involving the importation of labour, which was also deployed in New Caledonia (as demonstrated by Bencivengo, here and 2012; Le Meur, 2012). In an attempt to capture the multiple effects and, particularly, the negative impacts of mining on local and national economies in terms of economic performance, bad management, conflictuality and political regime type, the discursive shaping of the mining narrative as an expression of a resource curse was widely debated from the late 1980s (Rosser, 2006: 7; Robinson et al., 2006). The theory of the resource curse enjoyed considerable success in the circles of international development practitioners and economists as it offers a simple foil which allows the promotion of developmentbased solutions. This model tends to force heterogeneous processes into the Procrustean bed of a single normative and explanatory frame which conceals the specific features of local and national historical trajectories. Behind the catch-all (and not very sociological) category, it is necessary to decode the power relationships between actors, the collusions and alliances, the rent logics of states, the ways in which multinational mining companies establish themselves as physical and institutional enclaves, the local responses and reinterpretations etc. (Le Meur et al., 2013). These different ingredients constitute the political economy of the mine, and the resource curse constitutes not only its veil but also an actant - "a force in themselves" (Roe, 1994: 2) - in that the term legitimizes political choices, particularly while leaving aside the role of the mining companies and their country of origin as clearly demonstrated by the case of Nauru. The opening of the 'black box' that constitutes the discourse on the resource curse also opens up the way (or voice) for alternative narratives, i.e. counterstories in the sense of Roe, that invert the resource curse to transform it into an opportunity, under the condition that key elements of the societal context are taken into account (Bebbington et al., 2008; O'Faircheallaigh, 2012).

The resource curse or opportunity, the two faces of this narrative, intersect in the political field of other narratives, for example the narrative analyzed by Minerva Chaloping-March (pp. 93106) for the Philippines. The idea of "resource nationalism" would appear to represent a nationally constructed narrative, and possibly one constructed by a rentier state, in a globalized capitalist context, the power of which varies among other things based on commodity price cycles (see Bremmer and Johnston, 2009; Ward, 2009). Chaloping-March moves the problem in the direction of the relationship between national and local or, more precisely, between sovereignty and citizenship. The question she raises can be formulated as follows: To what extent is the narrative of national independence based on the controlled exploitation of mining 
resources the object of a national political debate and is it shared by a wide social base? This type of question arises in New Caledonia where the separatists placed economic control over the mining and processing of nickel at the centre of the political strategy from the late 1990s (cf. Grochain, 2013; Grochain et al., forthcoming), and where the 'loyalist' political leaders surprisingly seize upon the argument of acquiring a stake in the mining industry.

In the case of the Philippines, the resource nationalism functions as a kind of metanarrative structured by the controversies between narratives and counterstories, which also constitute the links between actor groups and the national and international political-administrative levels. In terms of a response to the causal sequence devised at national level (economic liberalization $=>$ investments in mining $=>$ growth $=>$ sustainable development $=>$ justice and equity), a discourse of local control over the exploitation of resources and protection of the environment exists that originates from political coalitions and networks, which also evoke the argument of resource nationalism themselves. Chaloping-March also demonstrates very clearly the role of key events (environmental disasters or new mining regulations) in the construction of policy narratives. In the same nationalist vein, albeit in a register relating to cultural heritage, archaeological discoveries confirming the antiquity and continuity of a mining operation originating in pre-colonial times make it possible to root a recent mining operation run by a Chinese company in a legitimate national narrative as in the Laotian case studied by Mayes and Chang (2013). In contrast, in a text on the complex relationship between archaeological digs and mining in Fiji, Nakoro (2011) describes a situation characterized by opposing logics of heritage preservation and mineral extraction while Bainton et al., (2011) show how the programme for the management of the cultural heritage arising from an agreement signed with the company operating the Lihir gold mine in Papua New Guinea is manipulated in the local political narratives and arenas.

The industrialists also tell stories, of course. ${ }^{14}$ As John Burton (pp. 37-51), who returns to the controversies that accompanied the operation of Porgera mine in Papua New Guinea (see also Filer, 1999) in his contribution, shows, under pressure from the governments and/ or local or international civil society, the mine operators ended up producing an impossible metanarrative (in the above-defined sense of a synthesis of different or concurrent policy narratives), which attempts to combine the maximization of the company's profit and the sustainable development of the communities, particularly in the form of the corporate social and environmental responsibility discourse. The examination of the companies practices reveals the fragmentation or dilution of responsibilities that lies behind the apparent coherence of the discourse (cf. Filer, Burton and Banks, 2008). Emery Roe notes, however, that the policy narratives - and the CSR-type discourse and global regulations promoted by multinational mining concerns belonging to the International Council on Mining and Medals (ICMM) are policy fragments produced by private operators - are not validated or invalidated by "reality":

"[ They] often resist change or modification even in the presence of contradicting empirical data, because they continue to underwrite and stabilize the assumptions for decision making in the face of high uncertainty, complexity, and polarization. " (Roe, 1994 : 2)

Like the 'master narratives' (of development, modernization etc.), the policy narratives endure on the basis of the credit they acquire and this credit is less related to the correlation between the facts and interpretations than to the solidity of the alliances formed and the legitimizing force of the narrative that is produced. It is a matter of degree but this specific balance gives a particular hue to the political controversies compared to the scientific controversies. ${ }^{15}$

\section{Mining narratives, rhetoric and identity}

La section précédente a permis d'aborder, de mThe previous section enabled us to broach, sometimes indirectly, the topic of the function of mining narratives. We must now examine the question regarding their purpose. In his contribution on the multiple narratives and geographies, in which the mining trajectory of Ok Tedi in Papua New Guinea is rooted (see also Hyndman, 2005), Dan Jorgensen (pp. 23- 36) sets out to differentiate between the instrumental or strategic functions of the narratives (and myths) and their non-instrumental functions

14. The narrative forms originating from other groups of actors who have a different relationship with time could be added here: geologists, who work in the context of a very long telluric term, and engineers, who are constrained by the structural urgency of finding solutions to current problems. We would like to thank Michel Jébrak for drawing our attention to this point.

15. On the technological controversies, see Callon (1981), on the scientific controversies, see Latour (1989) and on the philosophical controversies, see Fabiani (1997). In his essay on reactionary rhetoric, Albert Hirschmann (1991) clearly demonstrates how arguments can reverse in value without relinquishing their effectiveness. 
based on the particular case of a myth of origin with unexpected developments. The first involve the mobilization and adaptation of narratives for the purpose of justifying access to the mining revenues. Thus the narratives of origin serve in providing a basis for land claims relating to areas subject to current or future expropriation for mining purposes. These claims can take forms that are not directly territorial and involve networks of clans or chieftaincies or ritual links (Jorgensen here; Horowitz, 2003; Brutti, 2007; Crook, 2007; Le Meur, Horowitz, Mennesson, 2013). The justificatory function of these narratives also resides in the explanation of the creation and existence of the mineral wealth (Biersack, 1999) which refers to an understanding of the land as a material and immaterial good (Strathern, 2009).

The distinction between the instrumental and non-instrumental functions of narratives proposed by Jorgensen prompts two questions relating to the narrative purpose: Why tell? To persuade, negotiate, describe, remember, exist?; and the target (or narratee): Who does one address when one is seeking to persuade, negotiate, describe, remind, exist?

Several articles in this volume highlight in an instrumental way the desire to control the territory and resources, which is expressed through claims and policies that can be located at the local (Jorgensen, Bacalzo et al.) or national (Chaloping-March, Nanau) level. These strategies may be translated into sovereignty terms by dissociating this concept from its traditional usage in association with the state and adopting a broad and exploratory definition: sovereignty as an act of 'self-positioning':

" the ability of an entity to designate both its own identity and the scope of its authority. " (Joyce, 2013 : 35)

Sovereignty can take localized forms - frequently at present in the context of reformulations that borrow from the indigenous discourse - and is sometimes qualified as "internal sovereignty" in the context of settler colonies (New Caledonia, Australia, Canada etc.). ${ }^{16}$ The case presented by James Leach (pp. 53-62) is interesting in this context because it is slightly out of sync with the issue of mining and because of this makes it possible to answer the question regarding the non-instrumental dimension of the narratives associated with mining posed by Jorgensen. Highlighting the idea of "mutual possession" of the land and of the human collective (beyond the classical formulation of man belonging to the Earth) and the landscape as an "emergent animate process", Leach shifts the problem towards the existential domain: the narratives he recounts are narratives of life, the continuity of the community as a collective, of persistence in existence (going beyond and extending the scope of the idea of livelihood or subsistence mode). The move away from the instrumental function is simultaneously a move away from the register of ownership that had become standard in the negotiations between local populations and mining companies, as demonstrated, for example, by Colin Filer when he refers to the rise of an "ideology of landownership" (2006; see also Jorgensen, 2004) in Papua New Guinea in this context. The latter, which results from the mandatory response to the mining operators' demand for development, can assume more or less exclusive or inclusive forms, which, as Bacalzo Schwoerer et al (pp. 63-76) recall in the introduction to their article (see also Golub 2007), also vary in terms of social forms and kinship and relationship patterns. These authors also stress the relationship between the practical enactment of the ideology of land ownership and the phase in the mining cycle: the hypothesis would be that of a trend for the greater inclusion of local populations in the preliminary preexploitation phases.

Jorgensen's text (pp. 23-36) deliberately leaves open the question of the qualification of the non-instrumental functions of certain mining narratives, in particular those that surprisingly incorporate elements combining the myth of the lost tribes of Israel and the results of modern genetics. It could be suggested that the main non-instrumental function of these narratives is existential: combined with the persistence of the practices and knowledge that accompany them, they help the community to continue concretely and symbolically in its existence while honouring its debt to nature (Esposito, 2000; Strathern, 2009). Of course, one could object that a narrative that justifies the life of a collective assumes an instrumental function. Even if the brutal intrusion of global capital generates an effect involving the compression of time, the answer here may lie in taking different temporalities into account. Analysing the logics of exchange, Parry and Bloch (1989) differentiate between two major types of transactional orders, according to whether they are based on a duration inferior or superior to that of human life. Analogously, more instrumental and strategic narratives would be used to negotiate the intrusion of the mine and the urgency it engenders, on the one hand, and the discourses rooted in an extended duration and continuity, on the other. These differences

16. See, in particular, Evans et al. (2013). For the link between indigenousness, sovereignty and mining issues in New Caledonia, see Demmer (2007), Levacher (in press); Leblic (2007) and Graff (2012) return to the links between indigenousness, sovereignty and decolonization in the same territory. 
in temporality are analyzed by Leach (pp. 5362) from a similar perspective. As Jorgensen demonstrates here, these narrative forms, which deal with a collective's mode of existence, can also express the desire of a social group to extend its horizon beyond the local when based in Christian universality, for example. ${ }^{17}$

From a pragmatic point of view, the way in which the narratives circulate and change demonstrates the extensive intertwining between instrumental and non-instrumental registers. This interweaving follows a logic of 'bricolage' involving the mobilization of heterogeneous elements, i.e. an intertextual logic that generates narrative innovation and not repetition. ${ }^{18}$ This logic of assemblage does not prevent one narrative register from dominating in the organization of these mining narratives at a given time. This is what we observe in a location in the south of New Caledonia (Thio, Borendi) which is characterized by a secular and often conflictual experience of nickel mining. The narration of this experience by the local actors, particularly during its moments of tension, adopts a largely religious register (i.e. Christian but not exclusively) which is interwoven with and interprets the circumstances. ${ }^{19} \mathrm{~A}$ form of "narrative identity" is created through these narratives as a way of establishing coherence in terms of the duration of the action and the agent (Ricœur, 1990: 137-139; Somers, 1994), ${ }^{20}$ which both organizes the existential continuity of the collective and, in its plasticity, makes it possible to deal with the upheavals generated by the intrusion of mining in the context of a very unequal balance of power. This is demonstrated by Doris Bacalzo et al. (pp. 63-76), in particular, in their detailed description of the transformation of local social forms (the "clan" in particular) as a response to the obligation for the populations to position themselves in the competition for access to a share of the mining rent. Given that, as described here, the pressure from mining is growing and becoming more concrete, the move to less inclusive justification discourses could also be interpreted in the context of a continuum ranging from a general existential response to more competitive instrumental hardening (on this point see also Bainton, 2009; Le Meur, forthcoming).
Manipulation of the idea of narrative identity remains complicated in this case in that, based on their actual function, the narratives - ways of emplotment through causal interlinking - can contribute to the expression and definition of networks - actors, networks or mechanisms aimed at constructing and legitimizing forms of profit-sharing, mobilization and alliance (Latour, 2006). The composition of the collective moves beyond the indigenous group to include all kinds of different spokespersons, mediators and allies. This approach, which Bacalzo, Schwoerer et al. (pp. 63-76) begin to explore in their text (see also Horowitz, 2012), is promising and would merit a more systematic description, which would also enable the linking of this perspective with situations in which the narratives appear more directly indexed to clearly identified groups of actors, as is the case in the text presented here by John Burton (see also Le Meur, 2015)

\section{Narrative and narrative-making: the question of the narrator}

In this final section of the introduction we will return to a key point which has been deliberately omitted up to now, that is the question of the narrator. As we stated in the first section of the introduction a narrative assumes the existence of a narrator and involves a narratee: Who is telling the story and for whom? The mining narrative has an intentionality which must be situated in relation to this narrator/narratee pair in a given historical context while also keeping in mind that some of these narratives do not have an author. People tell stories to get people to act, to legitimize a presence and/or action, and also, as we have seen, for non-instrumental, existential purposes which mobilize and contribute to the reproduction of the aforementioned authorless narratives. Who produces the mining narratives and to what end? The main distinction in this regard arises between the narrator actor and narrator observer. Does the narrative involve a direct written first-person testament produced by an observer who is more or less external to the described situation? The texts collected here are often complex from this point of view as they

17. Conversely, Francesca Merlan (1994) speaks of "narratives of survival" in her analysis of contemporary Aboriginal narratives reporting the brutality of colonial relations in north Australia.

18. We would like to thank Dan Jorgensen for drawing our attention to this point.

19. Study being carried out in the context of the Nerval (Négocier, évaluer, reconnaitre la valeur des lieux) programme and financed by the CNRT "Nickel and its environment".

20. Ricœur sees narrative identity as an expression of "the dialectic between ipseity and sameness" (1990: 167) whereby ipseity refers to a reflexivity that questions the temporal continuity at the root of the idea of sameness. Ricœur provides the following definition of the narrative identity in an earlier text (1985: 442), which highlights the permeability between historiographical and literary narratives (on this point, see also White, 2009): "The fragile offspring of the union of history and fiction, it is the assignation to an individual or community of a specific identity which can be called their narrative identity." 
include narrative elements that are reported or recorded (intradiegetic level), written or spoken in the first person, and analyses originating from authors who, in the case of ethnographic narratives, are themselves in the situation of participant observers. Stuart Kirsch's proposal for a "reverse anthropology" is the one that appears to go further in terms of the erasing of the anthropologist as a narrator with a view to creating greater space for local stories and interpretations:

"The concept of reverse anthropology was first used by Roy Wagner [...] to describe how Melanesian cargo cults engaged with capitalist notions of profit, wage labour, and production. Wagner argued that cargo cults were the interpretative counterpart to the study of culture, and consequently a kind of reverse anthropology. I expand on this analogy by examining how the Yonggom deploy indigenous analysis in their political struggles with the mining company and the state. I also show how insights derived from indigenous analysis can contribute to contemporary political and theoretical debates on these issues. " (Kirsch, $2006: 2-3$ )

This is one of the 'ethnographic' modes of narration referred to by John Burton in his typology of the forms of emplotment of mining, which does not forget that the local populations are historical, political and reflective actors. This point could appear trivial. Yet the narratives produced by the actors directly affected by the issue of mining are often sheathed in a narrative veil (extradiegetic), which directs the reading of the narrative and prevents the full appreciation of all of the motivations, including their inconsistencies and possible contradictions.

As an activity involving the organization selection, editing and assembly - of narratives originating from field work (cf. Davis, 1999, quoted above), ethnographic writing can also combine a complex network of discourses by different authors and narrators - something that is also demonstrated by John Burton. The latter proposes a partially homodiegetic narrative as it refers to a polemic in which he was directly involved. At the same time, in his analysis he uses not only the discourses of development and corporate social responsibility but also a cinematographic narrative, the film Avatar, to explain the positions of other actors and, particularly, that of the NGO Mining Watch which criticizes him. The construction of his argument is based on the interweaving of a plurality of narrative modes.
In a different register, Florence Giulani (pp. 165-174) presents an emplotment that is used on two levels. She recounts the tribulations encountered by a project inspired by Land Art in an orphaned mine: the project was welcomed by the South Province of New Caledonia but its scope was reduced under the pressure of various technical and political obstacles. She then presents a multi-voice artistic installation involving, in particular, the women from the tribu (colonial administrative unit in New Caledonia) of Saint-Louis. The latter are invited to "heal" the mountain gouged by the mine by means of weaving. In doing this they become the custodians of a story that is both materialized through their production and conveyed by their discourse on the mine.

The workings of recounted stories and narratives used for often strategic purposes are the object of socially and politically indexed interpretations. The colonial prospector serves both his own glory and that of his homeland by tirelessly attempting to discover new ore seams and extend the mining territory. These two levels of reading are identifiable, but the author of the prospection report tells his story as embedded in a localized space and time: this is far removed from the quest for "abolished time" which Thierry Hentsch (2005) sees at the root of the major western narratives (see also Fabian, 2006). The prospection report describes a series of "gestures" which, for Yves Citton, situates this type of text "at the intersection of life and art to the extent that it represents an aesthetic sensibility enshrined in the everyday texture of our practices" (2012: 56). ${ }^{21}$

As demonstrated by Eddy Banaré, the Kanak writer for his part is torn between the promises of independence, the dream of an economic boom and the preservation of ancestral lands. With respect to the ecologist association, it can form an alliance with an indigenous organization for the preservation of the environment while the latter will then find common ground with the mining company in the context of the idea of sustainable development (Horowitz, 2012; Dashwood, 2013). Thus the production of discourses and stories is often related to the exercise, contestation or conquest of a power that runs through a work on the history, in the dual sense of the historical frame and narrative. Be it literary, historical, or political or institutional in its aim, the narrative assigns or contests roles; this process may be more visible in a colonial context of more explicit domination.

21. Aux récits et rapports de prospection coloniaux font échos les trajectoires contemporaines d'orpailleurs artisanaux en Afrique de l'Ouest et ailleurs, qui expriment, loin de tout exotisme, la dureté des sociétés qui se constituent sur les frontières minières, mais aussi les normes et les valeurs qui s'y forgent, à la base d'une "économie morale de l'orpaillage " (Grätz, 2004). 


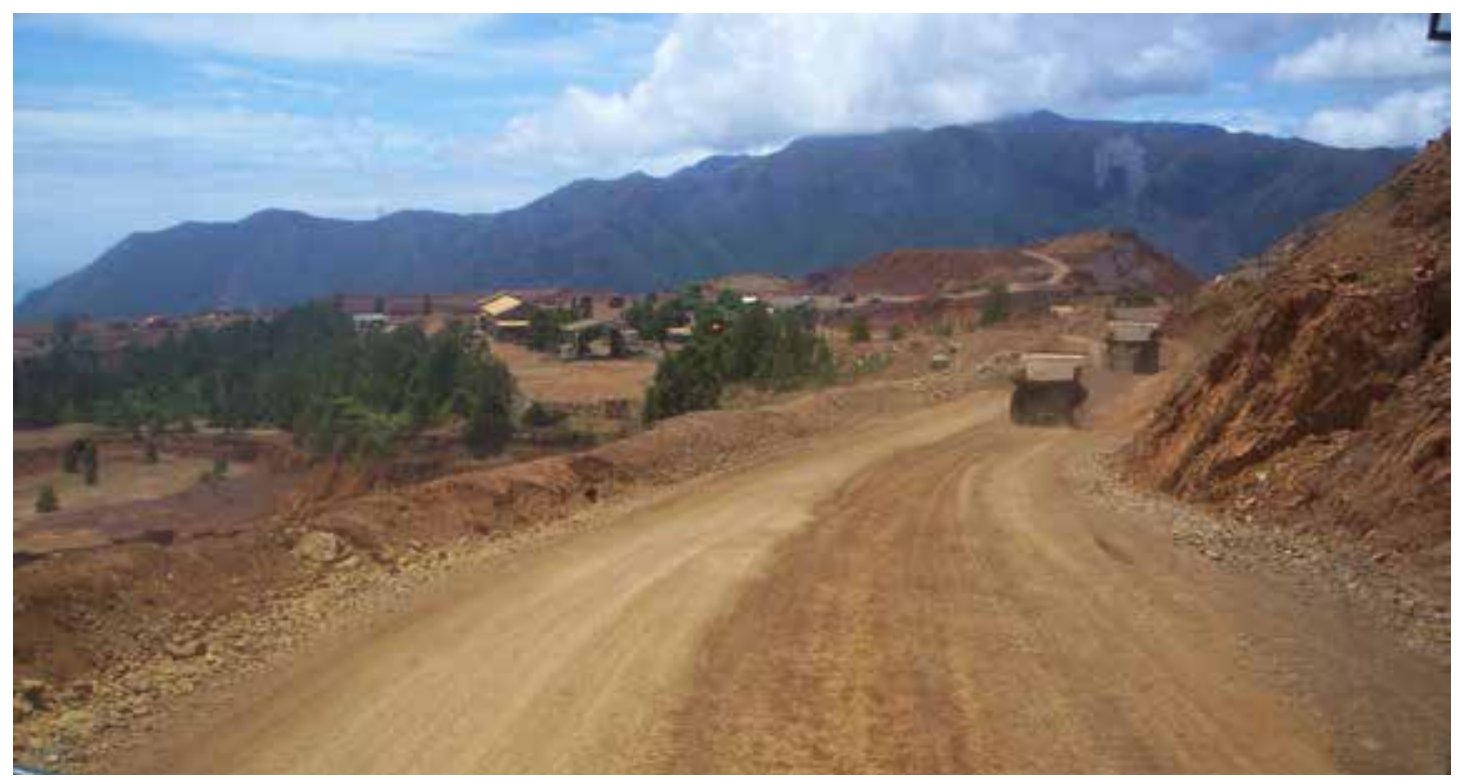

Рното 3. - Mining trucks ('rouleurs') on a haul road at Thio (2008, (C) Marlène Dégremont)

"The colonist makes history and he knows it. [...] The history he writes is therefore not the history of the country he is despoiling, but the history of his own nation's looting, raping and starving to death. " (Fanon, 2004: 15)

The exciting accounts of prospectors, the chronicles, the travel journals and short stories, and the novels and poetry that formed the first corpuses of mining narratives were written by colonial actors and aimed at colonial arenas. In the post-colonial context, depending on the perspective, stories would be told about the courage of the pioneer ancestors, kinds of "cultural heroes" and the "colonial trauma" described by Patrick Sultan: the fertile ground of memory, in which the creators come to draw, and which mixes "the snatching from a native country, the mass deportation, the forced transplantation, the destruction and disorganization of the ancestral locations, the desecration of sacred grounds, [and] the segregation (Sultan, 2011: 107).

At a higher level of aggregation, these narratives are part of a literature and philosophy of history and, in a way, of history itself. This is the route taken by Hayden White when he identifies an "historical imagination" (White, 1973, 2009) of nineteenth century Europe located in the founding period of the pioneering myths of the Oceania settler colonies. Through the chronicles, reports and press, it is possible to reconstruct an entire set of narratives whose writing borrows its codes from a range of literary genres, i.e. romance, tragedy, comedy and satire. However, this analogy should not be carried too far:

"The notion that sequences of real events possess the formal attributes of the stories we tell about imaginary events could only have its origins in wishes, daydreams, reveries. "(White, $1990: 27$ )

\section{Conclusion}

Mining is inseparable from the displacement of populations and plundering of lands, and sometimes generates extreme environmental, social and political violence. This dimension is often masked by the epic character of the master narratives relayed by the colonial press or conveyed in travel books, or through the formalism and appearance of objectivity of the reports on sustainable development and corporate social responsibility produced by companies and consultants.

It could be suggested that one of the functions of the texts created through mining is to circumvent - on a symbolic level but also increasingly from an institutional and legal perspective - the often poorly controlled environmental, economic, political and social spillover from this activity: conflicts and wars, accidents, meltdown and collapse of prices, corruption and clientelism. This production of texts involves a double attempt at rationalization (mining as a calculated undertaking) and poeticization (mining as an individual or collective achievement). This corpus is also comprised of unstated things (Barbançon, 1992), the most deafening of which is that generated by a colonial voice "premised on the silence of the native" (Said, 1993: 99) and still shapes the present of the mining locations and the narratives they continue to inspire. Through these narratives, empires 'dreamed themselves up' 
and memories and representations were forged, which are constitutive of the relationships that operate at mining sites and the activity of mining which the articles in this special issue evoke in a variety of registers.

In these different contexts, the shared authorless narrative - 'master narrative' or metanarrative, policy narrative - encounters the narrative as a story told by one or more situated authors who participate or not in the action being described or staged. Mining in the Pacific constitutes the basis of complex and interwoven narrative frames, which attempt to use a variety of registers ranging from individual experience to the algorithm of public policy to express the contradictions inherent in an activity that irrevocably transforms the people and landscapes. This volume includes texts which each contribute - in their own way and from the perspective of different locations (Fiji, Kiribati, Nauru, New Caledonia, Papua New Guinea, Solomon Islands) - to the expression, emplotment and interaction of these ways of telling stories about mining in the Pacific.

\section{Aknowledgements}

We warmly thanks Susan Cox for the translation of the French version of this article into English and John Burton for his careful reading.

\section{BIBLIOGRAPHY}

Anderson Benedict, 1983. Imagined Communities. Reflections on the Origin and Spread of Nationalism, London, Verso.

Bainton Nicholas A., 2009. Keeping the Network Out of View: Mining, Distinctions and Exclusion in Melanesia, Oceania 79 (1), pp. 18-33.

Bainton Nicholas A, Chris Ballard, Kirsty Gillespie and Nicholas Hall, 2011. Stepping Stones Across the Lihir Islands: Developing Cultural Heritage Management in the Context of a Gold Mining-Operation, International Journal of Cultural Property 18, pp. 81-110.

Ballard Chris and Glenn Banks, 2003. Resource Wars: The Anthropology of Mining, Annual Review of Anthropology 32, pp. 287313.

-, 2009. Between a rock and a hard place: corporate strategy at the Freeport mine in Papua, 2001-2006?, in B. Resosudarmo and
F. Jotzo (eds), Working with Nature against Poverty: Development, Resources and the Environment in Eastern Indonesia, Singapore, ISEAS, pp. 147-177.

Banaré Eddy, 2012. Les récits du nickel en Nouvelle-Calédonie (1853-1860), Paris, Honoré Champion, Francophonies.

-, 2014. Aspects littéraires de la recherche archivistique en Nouvelle-Calédonie: d'où vient le pionnier?, in V. Fillol et P.-Y. Le Meur (éds), Terrains océaniens : enjeux et méthodes, Paris, L'Harmattan, cahiers du Pacifique Sud, pp. 307-324.

BANks Glenn and Chris Ballard (eds), 1997. The Ok Tedi Settlement: issues, outcomes and implications, Canberra, ANU, Resource Management in Asia-Pacific, National Centre for Development Studies, Policy Paper n 27.

Barbançon Louis-José, 1992. Le Pays du nondit. Regards sur la Nouvelle-Calédonie, La Motte Achard, à compte d'auteur.

BAYARD Pierre, 2009. Le plagiat par anticipation, Paris, Éditions de Minuit.

Bebbington Anthony, Leonith Hinojosa, Denise Humphreys Bebbington, Maria Luisa Burneo and Ximena WarnaArs, 2008. Contention and Ambiguity: Mining and the Possibilities of Development, Development and Change 39 (6), pp. 887-914.

Benvivengo Yann, 2012. Immigration japonaise en Nouvelle-Calédonie: une illustration de l'affirmation du Japon dans le Pacifique, Journal de la Société des Océanistes 135 : Relations internationales et régionales en Océanie (S. Mohamed-Gaillard éd.), pp. 215-228.

Biersack Aletta, 1999. The Mount Kare python and his gold, American Anthropologist 101, pp. 68-87.

Bremmer Ian and Robert Joohnston, 2009. The rise and fall of resource nationalism, Survival 51(2), pp. 149-158.

Brenneis Donald and Fred Myers (eds), 1984. Dangerous Words: Language and Politics in the Pacific, New York, New York University Press

BRUTti Lorenzo, 2007. From fertility rituals to mining companies: Ecocultural issues and land rights in Oksapmin, Journal de la Société des Océanistes 125, pp. 249-255.

Burke Peter (ed.), 1991. New Perspectives on Historical Writing, Londres, Polity Press. 
Callon Michel, 1981. Pour une sociologie des controverses techniques, Fundamentae Scientae 2, pp. 381-399.

Clifford James, 2013. Returns. Becoming Indigenous in the Twenty-First Century, Cambridge, Harvard University Press.

Clifford James and Georges Marcus (eds), 1986. Writing Culture. The Poetics and Politics of Ethnography, Berkeley, University of California Press.

Cooper Frederick, 1997. Modernizing Bureaucrats, Backward Africans, and the Development Concept, in F. Cooper and R. Packard (eds), International Development and the Social Sciences. Essays on the History and Politics of Knowledge, Berkeley, University of California Press, pp. 64-92.

Coumans Catherine, 2011. Occupying Spaces Created by Conflict: Anthropologists, Development NGOs, Responsible Investment, and Mining (with CA comment by S. Kirsch), Current Anthropology 52 (S3), pp. S29-S43.

Crook Tony, 2007. 'If you don't believe our story, at least give us half of the money': claiming ownership of the Ok Tedi Mine, PNG, Journal de la Société des Océanistes 125, pp. 221-228.

Daswhood Hevina, 2013. The Rise of Global Corporate Social Responibility. Mining and the Spread of Global Norms, Cambridge, Cambridge University Press.

Davies Charlotte Aull, 1999. Reflexive Ethnography. A Guide to Researching Selves and Others, Londres, Routledge.

Dawson Andrew, Jenny Hockey and Allison James (eds), 1997. After Writing Culture: Epistemology and Praxis in Contemporary Anthropology, Londres, Routledge, ASA Monographs.

Demmer Christine, 2007. Autochtonie, nickel et environnement. Une nouvelle stratégie kanak, Vacarme 39, pp. 43-48.

Esposito Roberto, 2000. Communitas. The Origin and Destiny of Community, Stanford, Stanford University Press.

Evans Julie, Ann Genovese, Alexander Reilly and Patrick Wolfe (eds), 2013. Sovereignty. Frontiers of Possibility, Honolulu, University of Hawai'i Press.

FABIAN Johannes 2006 (éd. or. 1983). Le temps et les autres. Comment l'anthropologue construit son objet, préface d'Alban Bensa, Toulouse, Anarchasis.
-, 2006. The other revisited: Critical afterthoughts, Anthropological Theory 6 (2), pp. 139-152.

Fabiani Jean-Louis, 1997. Controverses scientifiques, controverses philosophiques. Figures, positions, objets, Enquête 5, pp. 11-34.

Fanon Frantz, 2011. Euvres, Paris, La Découverte.

Filer Colin, 1990. The Bougainville Rebellion, the Mining Industry and the Process of Social Disintegration in Papua New Guinea. Canberra Anthropology 13 (1), pp. 1-39.

- 2006. Custom, Law and Ideology in Papua New Guinea, The Asia Pacific Journal of Anthropology 7 (1), pp. 65-84.

- 2012, The development forum in Papua New Guinea: evaluating outcomes for local communities, in Marcia Langton and Judy Longbottom (eds), Community Futures, Legal Architecture: Foundations for Indigenous People in the Global Mining Boom, London, Routledge, pp. 45-58.

Filer Colin (ed.), 1999. Dilemmas of Development: The social and economic impact of the Porgera gold mine, 1989-1994, Canberra, Asia-Pacific Press.

Filer Colin, John Burton and Glenn Banks, 2008. The fragmentation of responsibilities in the Melanesian mining sector, in S. Ali and C. O'Faircheallaigh (eds), Earth Matters. Indigenous peoples, the extractive industry and corporate social responsibility, Sheffield, Greenleaf Publishing, pp. 163-179.

Filer Colin, Pierre-Yves Le Meur and JeanMichel Sourisseau (eds), à paraître. Local politics and large-scale mining. Perspectives from New Caledonia and Papua New Guinea, Canberra, ANU Epress.

Foster Robert J. (ed.), 1995. Nation Making. Emergent Identities in Postcolonial Melanesia, Ann Arbor, The University of Michigan Press.

-, 2002. Materializing the Nation. Commodities, Consumption, and Media in Papua New Guinea, Bloomington, Indiana University Press.

Fuentes Carlos, 1979 (éd. or. mexicaine 1975). Terra Nostra, Paris, Gallimard.

Genette Gérard, 2007. Discours du récit. Essai de méthode (volume regroupant Figure III : Discours du récit [1972] et Nouveau discours du récit [1983]), Paris, Seuil.

GrafF Stéphanie, 2013. Quand combat et revendication kanak ou politique de l'État français manient indépendance, décolonisa- 
tion, autodétermination et autochtonie en Nouvelle-Calédonie, Journal de la Société des Océanistes 134, pp. 61-83.

Golub Alex, 2007. From Agency to Agents: Forging Landowner Identities in Porgera, in J. F. Weiner and K. Glaskin (eds), Customary Land Tenure and Registration in Australia and Papua New Guinea: Anthropological Perspectives, Canberra, ANU Epress, pp. 57-72.

Grätz Tilo, 2004. Les frontières de l'orpaillage en Afrique occidentale, Autrepart 30, cahier thématique Gouverner les hommes et les ressources. Dynamiques de la frontière interne, (J.-P. Chauveau, J.-P. Jacob et P.-Y. Le Meur eds), pp. 135-150.

Greimas Algirdas Julien et Joseph Courtès, 1993. Sémiotique. Dictionnaire raisonné de la théorie du langage, Paris, Hachette.

Grochain Sonia, 2013. Les dynamiques sociétales du projet Koniambo, Nouméa, Éditions IAC, Études et Synthèse.

Grochain Sonia, David Poithily et Jean-Michel Sourisseau, à paraître. From Anticipation to Practice: Social and Economic Management Put to the Test in the Metals Sector. An Example in New Caledonia's North Province, in C. Filer, P.-Y. Le Meur and J.-M. Sourisseau (eds), Local Politics and LargeScale Mining. Perspectives from New Caledonia and Papua New Guinea, Canberra, ANU Epress.

Hartog François, 2003. Régimes d'historicité. Présentisme et expérience du temps, Paris, Seuil.

—, 2005. Évidence de l'histoire. Ce que voient les historiens, Paris, Seuil.

Hau'ofa Epeli, 1993. Our Sea of Island, in E. Waddell, V. Naidu and E. Hau' ofa (eds), New Oceania: Rediscovering our Sea of Island, Fiji, University of the South Pacific, School of Social and Economic Development, pp. 2-19.

Hentsch Thierry, 2005. Le temps aboli : l'Occident et ses grands récits, Montréal, Presses de l'Université de Montréal/Bréal.

Hirschman Albert O., 1991. Deux siècles de rhétorique réactionnaire, Paris, Fayard.

Horowitz Leah S., 2003. La micropolitique de la mine en Nouvelle-Calédonie, Analyse des conflits autour d'un projet minier au sein d'une communauté kanak, Journal de la Société des Océanistes 117 : Nouvelle-Calédonie, 150 ans après la prise de possession (I. Leblic éd.), pp. 254-271.

-, 2012. Translation Alignment: ActorNetwork Theory and the power dynamics of environmental protest alliances in New Caledonia, Antipode 44 (3), pp. 806-827.

Hyndman David, 2005. Shifting Ecological Imaginaries in the Ok Tedi Mining Crisis in Papua New Guinea, Journal de la Société des Océanistes 120-121: Ethnoécologie en Océanie (F. Brunois éd.), pp. 76-93.

Imbun Benedict, 2011. Anthropology of Mining in Papua New Guinea Greenfields, New York, Nova Publishers.

Jorgensen Dan, 1990. Placing the past and moving the present: Myth and contemporary history in Telefolmin, Culture 10, pp. 47-56.

-, 2004. Who and what is a landowner? Mythology and marking the ground in a Papua New Guinea mining project, in Alan Rumsey and James Weiner (eds), Mining and Indigenous Lifeworlds in Australia and Papua New Guinea, Wantage, Sean Kingston Publishing, pp. 68-100.

Joyce Richard, 2013. Competing Sovereignties, London, Routledge.

KIRSCH Stuart, 2006. Reverse Anthropology: Indigenous analysis of social and environmental relations in New Guinea, Stanford, Stanford University Press.

Latour Bruno, 1989. La science en action, Paris, Seuil.

-, 2002. La fabrique du droit. Une ethnographie du Conseil d'État, Paris, La Découverte.

-, 2006. Changer la société - Refaire de la sociologie, Paris, La Découverte.

Leblic Isabelle, 1993. Les Kanak face au développement. La voie étroite, Grenoble, PUG.

-, 2007. Kanak Identity, New Citizenship Building and Reconciliation, Journal de la Société des Océanistes 125, pp. 271-282.

Leith Denise, 2003. The Politics of Power: Freeport in Suharto's Indonesia, Honolulu, University of Hawai'i Press.

Le Meur Pierre-Yves, 2012 (6-8 nov.). The New Caledonia/France relationship through the lens of the mine. Colonization and globalization, old and new, Pacific History Association Conference 2012 Generations: History in the Pacific, Histories in the Future, Panel "Revisiting the "French Pacific": connected or disconnected histories?», Wellington (NZ).

—, 2014. Anthropologie de la mine: travailler sur/dans/avec le secteur minier en NouvelleCalédonie, in V. Fillol et P.-Y. Le Meur (éds), Terrains océaniens : enjeux et méthodes, Paris, 
L'Harmattan, Cahiers du Pacifique Sud, pp. $175-194$.

- à paraître. Conflict and agreement. The politics of Nickel in Thio, New Caledonia, in C. Filer, P.-Y. Le Meur and J.-M. Sourisseau (eds), Local Politics and Large-Scale Mining. Perspectives from New Caledonia and Papua New Guinea, Canberra, ANU Epress.

Le Meur Pierre-Yves, Chris Ballard, Glenn Banks and Jean-Michel Sourisseau, 2013. Two islands, four states: Comparing resource governance regimes in the Southwest Pacific, in J. Wiertz (ed.), Proceedings of the $2^{\text {nd }}$ International Conference on Social Responsibility in Mining (SRMining 2013, Santiago, Chile), University of Queensland, GECAMIN-SMI, pp. 191-199.

Le Meur Pierre-Yves, Leah Horowitz and Thierry Mennesson, 2013. "Horizontal» and "vertical» diffusion: the cumulative influence of Impact and Benefit Agreements (IBAS) on mining policy-production in New Caledonia, Resources Policy 38, pp. 648-656.

LETTÉ Michel, 2009. Débordements industriels dans la cité et histoire de leurs conflits aux $\mathrm{XIX}^{e}$ et $\mathrm{XX}^{e}$ siècles, Documents pour l'histoire des techniques 17, pp. 163-173.

LEVACHER Claire, à paraître. Indigenous people rights and the Goro-Nickel mining project in New Caledonia, in C. Filer, P.-Y. Le Meur, and J.-M. Sourisseau (eds), Local Politics and Large-Scale Mining. Perspectives from New Caledonia and Papua New Guinea, Canberra, ANU Epress.

Lyotard Jean-François, 1979. La condition postmoderne. Rapport sur le savoir, Paris, Éditions de Minuit.

Masquelier Bertrand et Jean-Louis Siran (éds), 2000. Pour une anthropologie de l'interlocution. Rhétoriques du quotidien, Paris, L'Harmattan.

Mayes Warren and Nigel Chang, 2013. Cultural heritage management and local participation in the development of the Sepon mine, in J. Wiertz (ed.), Proceedings of the 2 nd International Conference on Social Responsibility in Mining (SRMining 2013, Santiago, Chile), University of Queensland, GECAMIN-SMI, pp. 55-62.

Mcintosh Ian, 2004. The iron furnace of Birrinydji, in Alan Rumsey and James Weiner (eds), Mining and Indigenous Lifeworlds in Australia and Papua New Guinea, Wantage, Sean Kingston Publishing, pp. 12-30.
Merlan Francesca, 1994. Narratives of Survival in the Post-Colonial North, Oceania 65, pp. 152-173.

Merle Isabelle, 1998. La construction d'un droit foncier colonial. De la propriété collective à la constitution des réserves en Nouvelle-Calédonie, Enquête 7, pp. 97-126.

Montalbetti Christine, 1998. Gérard Genette: une poétique ouverte, Paris, Bertrand-Lacoste.

Mosse David, 2004. Is Good Policy Unimplementable? Reflections on the Ethnography of Aid Policy and Practice, Development \& Change 35 (4), pp. 639-671.

Nakoro Elia, 2011 (21-25 Nov). Mining and Cultural Heritage Preservation in Fiji, International conference Mining in the Pacific: History, issues, perspectives, Noumea.

Nash June, 1993 (1 ${ }^{\mathrm{e}}$ éd. 1979). We Eat the Mines and the Mines Eat Us. Dependency and Exploitation in Bolivian Tin Mines, New York, Columbia University Press.

O'Faircheallaich Ciaran, 2012. Curse or opportunity? Mineral revenues, rent-seeking and development in Aboriginal Australia, in Marcia Langton and Judy Longbottom (eds), Community Futures, Legal Architecture: Foundations for Indigenous People in the Global Mining Boom, London, Routledge, pp. 45-58.

PARry Jonathan and Marc Bloch (eds), 1989. Money and the morality of exchange, Cambridge, Cambridge University Press.

Passeron Jean-Claude, 1991. Le raisonnement sociologique. L'espace non-poppérien du raisonnement naturel, Paris, Nathan.

Polier Nicole, 1996. Of mines and Min: modernity and its malcontents in Papua New Guinea, Ethnology 35, pp. 1-16.

Propp Vladimir, 1970 (1 éd. 1928). Morphologie du conte, Paris, Seuil.

Richer de Forges Bertrand et Michel Pascal, 2008. La Nouvelle-Calédonie, un "point chaud " de la biodiversité mondiale gravement menacé par l'exploitation minière, Journal de la Société des Océanistes 126-127: Spécial Environnement dans le Pacifique (J. Trichet et I. Leblic éds), pp. 95-112.

Ricceur Paul, 1983. Temps et récit, vol. 1 : L'intrigue et le récit historique, Paris, Seuil.

-, 1984. Temps et récit, vol. 2 : La configuration dans le récit de fiction, Paris, Seuil.

—, 1985. Temps et récit, vol. 3 : Le temps raconté, Paris, Seuil. 
—, 1990. Soi-même comme un autre, Paris, Seuil.

Robinson James, Ragnar Torvik and Thierry Verdier, 2006. Political foundations of the resource curse, Journal of Development Economics 79, pp. 447-468.

Roe Emery, 1994. Narrative Policy Analysis. Theory and Practice, Durham-London, Duke University Press.

Rosser Andrew, 2006. The Political Economy of the Resource Curse: A Literature Survey, Brighton, Institute of Development Studies, Working Paper 268.

SAID Edward, 2000. Culture et impérialisme, Paris, Le Monde.

Sanjek Richard, 1990. The Ethnographic Present, Man (N.S.) 26, pp. 609-628.

SAussol Alain, 1979. L'Héritage. Essai sur le problème foncier mélanésien en Nouvelle-Calédonie, Paris, Société des Océanistes, Publication de la SdO 40.

Shipton Parker and Mitzi Goheen, 1992. Introduction. Understanding African Landholding: Power, Wealth and Meaning, Africa 62 (3), pp. 307-325.

Shlomowitz Ralph and Doug Munro, 1992. The Ocean Island (Banaba) and Nauru labour trade 1900-1940, Journal de la Société des Océanistes 94 (1), pp. 103-117.

SidAWAY James, 2007. Enclave space: a new metageography of development?, Area 39 (3), pp. 331-339.

Sivaramakrishnan K., 2000. Crafting the Public Sphere in the Forests of West Bengal, American Ethnologist 27 (2), pp. 431-461.
Somers Margaret, 1994. The Narrative Constitution of Identity: A Relational and Network Approach, Theory and Society 23 (5), pp. 605-649.

Strathern Marilyn, 2009, Land: Intangible or Tangible Property?, in T. Chesters (ed.), Land Rights. The Oxford Amnesty Lectures 2005, Oxford, Oxford University Press, pp. 13-38.

Sultan Patrick, 2011. La scène littéraire postcoloniale, Paris, Le Manuscrit, L'Esprit des Lettres.

TAussig Michael, 2010 (1 $1^{\mathrm{e}}$ éd. 1980). The Devil and Commodity Fetishism in South America, Chapel Hill, The University of North Carolina Press.

Thompson Anne-Gabrielle, 2000. John Higginson : un spéculateur-aventurier à l'assaut du Pacifique (Nouvelle-Calédonie, Nouvelles-Hébrides), Paris, L'Harmattan.

Veyne Paul, 1978. Comment on écrit l'histoire, Paris, Seuil.

WARD Halina, 2009. Resource nationalism and sustainable development: a primer and key issues, London, IIED, Working Paper.

White Geoffrey and Karen Ann Watson GeGEO (eds), 1990. Disentangling. Conflict Discourse in Pacific Societies, Stanford, Stanford University Press.

White Hayden, 2009 (éd. or. américaine 1973). Poétiques de l'histoire, Labyrinthe 33 (2), pp. 21-65.

-, 1973. Metahistory: The Historical Imagination in Nineteenth-Century Europe, Baltimore, John Hopkins University Press.

-, 1990. The Content of the Form: Narrative Discourse and Historical Representation, Baltimore, John Hopkins University Press. 